\title{
Bio-Based Value Chains Potential in the Management of Cacao Pod Waste in Colombia, a Case Study
}

\author{
Diana C. Meza-Sepúlveda ${ }^{1}$ (D) Ana M. Castro ${ }^{2}$, Annie Zamora ${ }^{3}$, Jorge W. Arboleda ${ }^{4,5}$, Adriana M. Gallego ${ }^{4,5, *}$ \\ and Anyela V. Camargo-Rodríguez ${ }^{6, *(D)}$ \\ 1 Grupo de Desarrollo Agroindustrial, Facultad de Ciencias Agrarias y Agroindustria, \\ Universidad Tecnológica de Pereira, 660004 Pereira, Colombia; dcmeza@utp.edu.co \\ 2 Hands \& Crops. S.A.S., 760041 Cali, Colombia; handsandcrops@gmail.com \\ 3 Federacion Nacional de Cacaoteros, Fedecacao, 110311 Bogotá, Colombia; annie.zamora@fedecacao.com.co \\ 4 Centro de Bioinformática y Biología Computacional de Colombia—BIOS, 170004 Manizales, Colombia; \\ jorge.arboleda@bios.co \\ 5 Grupo de Biotecnología, Instituto de Biología, Universidad de Antioquia, 050015 Medellín, Colombia \\ 6 National Institute of Agricultural Botany, Cambridge CB3 OLE, UK \\ * Correspondence: adriana.gallego.02@gmail.com (A.M.G.); anyela.camargorodriguez@niab.com (A.V.C.-R.)
}

Citation: Meza-Sepúlveda, D.C.; Castro, A.M.; Zamora, A.; Arboleda, J.W.; Gallego, A.M.;

Camargo-Rodríguez, A.V. Bio-Based

Value Chains Potential in the

Management of Cacao Pod Waste in Colombia, a Case Study. Agronomy 2021, 11, 693. https://doi.org/ 10.3390/agronomy11040693

Academic Editors: Alfonso Exposito, Julio Berbel and Javier

Martínez Dalmau

Received: 12 March 2021

Accepted: 29 March 2021

Published: 5 April 2021

Publisher's Note: MDPI stays neutral with regard to jurisdictional claims in published maps and institutional affiliations.

Copyright: (c) 2021 by the authors. Licensee MDPI, Basel, Switzerland. This article is an open access article distributed under the terms and conditions of the Creative Commons Attribution (CC BY) license (https:/ / creativecommons.org/licenses/by/ $4.0 /)$.
Abstract: Agriculture generates 11.4 billion tons of biomass worldwide, including residues from crop production and industrial processing. Improper disposal of agricultural residues results in environmental pollution and the waste of valuable biomass resources. Management of agricultural waste is particularly suboptimal in developing countries where low added-value traditional practices to manage the residues are commonplace. A bioeconomy approach to better manage agricultural waste is to use renewable biological resources from land and sea to produce new materials and energy, allowing the development of bio-based value chains (BBVC). This study explored the potential of BBVC in the management of cacao pod husk $(\mathrm{CPH})$, the primary residual biomass generated from the production of cacao in Colombia. Thus, a literature review on cacao pod husk (CPH) management strategies and a survey for farmers from Caldas State in Colombia between August and November of 2020 were performed to identify the potentials and limitations of BBVC in the management of $\mathrm{CPH}$. Assessment of $\mathrm{CPH}$ management strategies suggested variable uses for $\mathrm{CPH}$ categorized in energy, food, and miscellaneous. Analysis of surveys indicated farmers are keen to implement strategies to better manage their agricultural waste, but that information is not available to them. Finally, an approach to develop a BBVC from cacao was proposed, which we plan to implement as a future research direction. We expect to impact the economic growth positively in the region with bio-based products in the market.

Keywords: bio-based value chains; biomass; cacao pod; bioeconomy; waste management

\section{Introduction}

Agriculture generates 11.4 billion tons of biomass every year. Agricultural biomass is made up of the resources containing non-fossil, organic carbon recently ( $<100$ years) derived from living plants, animals, algae, microorganisms, or organic waste streams [1]. The consequence of this intense farming is the generation of large amounts of agricultural residues. Agricultural residues are derived from crop production processes but are not used as food for humans or raw materials for the industry (e.g., cotton). These include both primary residues (in the form of stalks, leaves, roots, peels, husks, cobs, shells, nuts) and secondary residues (derived from processing activities like straw, sawdust, and waste woods). Similar features characterize the agricultural residues, and basic composition generally is referred as lignocellulosic [2]. However, the chemical composition of these residues may vary depending on their sources. Accordingly, the systematic identification, quantification, and characterization of such biomass chemical composition are the initial and most important steps during the research and application of biorefinery products. 
Consequently, with the increase in food production, agricultural residues are also expected to increase considerably [3]. Usually, the amount of agricultural residues exceeds food production (in terms of edible parts of the crops). More than half of all absolute dry matter in the global harvest are agricultural residues like cereal and legume straws; in tops, stalks, leaves, and shoots of tuber, oil, sugar, and vegetable crops; and in the pruning and litter of fruit and nut trees [1,4]. Large amounts of agricultural residues are widespread in large food producers of developing countries. Extensive cultivation areas characterize these countries accompanied by traditional practices to manage the residues (e.g., covering soil, composting agricultural residues, open burning in landfills, outdoor degradation). Open burning and outdoor degradation practices harbor a low added-value as they do not represent further increases in profitability or environmental benefits. Countries like Colombia produce $71 \mathrm{Mt}$ tons of agricultural residues/year from eight crops compared to $14 \mathrm{Mt}$ /year of edible production obtained from the same eight crops [5]. In contrast, Germany produces $40 \mathrm{Mt}$ of agricultural residues annually, mainly from cereals and oilseeds [6]. Although many factors contribute to waste volume differences (geographical context and arable land), it is essential to highlight that the countries localized on the equatorial belt are more sensitive to the effects of climate change, such as crop damage due to diseases, droughts, and flooding, which in turn increases the volume of residues due to crop spoilage [7].

The enormous amounts of agricultural waste generated by crop production represent a hazard to the environment and human health when they are not properly managed [8]. Practices to reduce or eliminate agricultural residues include on-farm burning, which has become very common, particularly in developing countries [9]. Waste burning results in soil moisture loss leading to less available moisture to sow the next crop, negatively affecting germination. Burning also affects soil fauna, particularly the population of earthworms and beneficial insects [10]. Furthermore, this practice generates greenhouse gases $\left(\mathrm{CO}_{2}\right.$, $\mathrm{CO}, \mathrm{CH}_{4}, \mathrm{~N}_{2} \mathrm{O}, \mathrm{SO}_{2}$ ), aerosols, particulate matter, smoke, volatile organic compound, and radioactive gases; thereby, exacerbating global and regional atmosphere chemistry [10]. In addition, the smoky emissions may lead to health threats like lung infection, chronic bronchitis, and asthma [11]. Another common practice used by farmers is to leave their agricultural waste in the field. Although this practice seems harmless, the accumulated waste could contain infested plant material, leading to pest and disease dissemination favoring the harvest lost [10]. Several factors, such as the lack of highly skilled farm labor, the lack of waste management policies in some areas, and the weak implementation of waste management policies in other locations, further intensifies the environmental burden of unmanaged agricultural waste [12].

A strategy to deal with agricultural waste lies in implementing bioeconomy initiatives based on the better management of plant biomass. Bioeconomy strategies are considered a new paradigm to address the depletion of natural resources and the valorization of residues due to global demands, consumption patterns, and other environmental, social, and economic challenges. Thus, a desirable bioeconomy approach for waste management is exploring the hidden potential of biomass through the development of bio-based value chains (BBVC) [1]. Adding value to the waste makes it possible to identify potential uses and develop circular economy models to balance the demand and supply of goods/food and environmental sustainability. Some of the benefits of using BBVC to manage agricultural residues are: (1) Agro-waste is not a threat to food security because edible food sources are not used; (2) findings from previous studies suggest that the lignocellulose byproducts, including corn stover, rice, and wheat straw, and pineapple and banana leaves, can be used to extract natural cellulose fibers with properties suitable for textile, bioplastics, and other industrial applications; (3) a large diversity of goods and new materials with high economic value can be used as energy sources; (4) the addition of value for agricultural residues can contribute to the development of BBVC and job generation; (5) contribution to minimizing on-farm burning to reduce the negative impacts on environmental and human health; (6) as raw materials, agricultural residues are attractive to large-scale industries as 
well as small scale processing in rural areas; and finally (7) agricultural residues as input for BBVC offer a possibility to implement circular models, closing material and energy flows and transforming linear production processes into circular or closed ones, and accordingly reducing the generation of waste [1].

Colombia is a country rich in natural resources whose main primary economic activity is agriculture. As a result, large amounts of agricultural residues are produced and left unmanaged annually. A particular crop to explore from a BBVC perspective is cacao. In Colombia, cacao cultivation accounts for more than 140,000 ha and generates considerable amounts of waste. The highest volume of residues from cacao is derived from the shells known as cacao pod husk (CPH), representing 52 to $70 \%$ of the fruit's wet weight. Thus, it is expected that CPH residues may reach roughly 2,100,000 $\mathrm{t}$ in 2021 in Colombia [13]. Although CPH represents a large proportion of cacao waste, minimal added-value management practices are implemented for this crop in Colombia. Some of the most common methods to manage $\mathrm{CPH}$ are either leaving the residue in the field without any treatment or cutting $\mathrm{CPH}$ into smaller pieces on the ground without any protection or treatment.

To develop a successful BBVC strategy to manage cacao residues, it is essential to have information on the characterization and potential uses of the $\mathrm{CPH}$ waste. This information provides insights into possible products to be developed and prioritized in a target region, thus reducing the knowledge gap about the potential uses of $\mathrm{CPH}$ and what could be done. Additionally, local information on the crop and how farmers currently manage their agricultural waste are requirements for the successful development of any BBVC strategy.

In this study, we explored BBVC in the context of the cacao chain in Colombia. We performed a literature review on the characterization and reported uses of $\mathrm{CPH}$ and a farmer survey carried in the Caldas region of Colombia. The survey allowed us to collect information regarding the current waste management practices carried out by cacao farmers in Caldas. Both literature review and farmers surveys were used as crucial elements to propose a cacao waste management strategy. We also discussed the socioeconomic conditions and the attitude of farmers regarding cacao waste management. Finally, we presented the $\mathrm{CPH}$ biomass as a raw material to develop a new BBVC that impacts the Colombian economic growth with valuable products in the market.

\section{Materials and Methods}

To design a strategy for implementing a BBVC from cacao waste in Colombia, we first chose a location. We selected the Caldas region based on the following regional conditions. First of all, Caldas has a strategic location at the geographical level. It is located in the Central Cordillera of the Colombian Andes; it is surrounded by two main rivers, Cauca and Magdalena, which is essential as a form of national river transport. Apart from accessibility through the rivers, Caldas is highly accessible by rail, high- and low-speed roads, and airports, which is crucial to any supply chain success in delivering products. Caldas is also very close to Bogotá, the capital of Colombia, where there is already infrastructure to process and transform raw biomass. Second, although coffee is the main agricultural product, other crops like cacao are increasing in importance. The reason is that for the farm families who grow coffee high up on the Andes, increasingly erratic and extreme weather conditions, such as excess rainfall and more frequent droughts, are threatening the production of coffee. Thus, farmers have had to diversify into more climate-resilient crops such as cacao [14]. Particularly for the Caldas region, climate change has favored temperature increases. Cacao is a crop naturally adapted to hot climatic conditions; thus, climate change in those areas favors cacao growth. Following this, we went through two main steps: (1) A literature review in Colombian cacao productions and residues, characterization, and uses of $\mathrm{CPH}$ worldwide and in Colombia, and (2) a survey for cacao farmers from the Caldas region in waste management practices.

To build state-of-the-art CPH management, we accessed various databases and indexed journals and looked for reports on CPH not only worldwide but in Colombia. Since we also wanted to determine the technological maturity of the $\mathrm{CPH}$-derived products 
reported in the review, we categorized the search as (1) cacao production and residual biomass in Colombia, (2) cycle and characterization of $\mathrm{CPH}$, and (3) uses of $\mathrm{CPH}$. The review gave us insights into the capacity to supply residual cacao biomass in Colombia and potential bioproducts derived from $\mathrm{CPH}$.

Regarding the surveys for cacao farmers of Caldas region, we wanted to inquire about the farmers' attitudes towards cacao agricultural waste management. A questionnaire with 29 categorical questions was designed (Supplementary File 1). The questionnaire was built between experts, including FEDECACAO (the national network of cacao farmers) and national and international allies. They included the Centro de Bioinformatica y Biologia Computacional de Colombia-BIOS and the company Hands \& Crops from Colombia, and the National Institute of Agricultural Botany from UK.

The farmer cohort who participated in the survey were members of the Association of Agricultural Producers (Asoprobel) located in the Caldas region. Asoprobel has 338 members distributed across the municipalities of Belalcazar, San Jose, and Viterbo. A total of 40 cacao farmers (over $10 \%$ of the associates) were randomly selected and informed, with the help of local Asoprobel, about the project's importance and purpose. Asoprobel facilitated communication and building trust between farmers and the team carrying out the survey and subsequent workshops. The survey was carried out over phone calls due to the pandemic restrictions in the second semester of 2020 between August and October. As data were confidentially considered, all telephone calls were recorded and monitored and lasted between 20 and $30 \mathrm{~min}$. Telephone calls were manually transcribed and digitalized in an excel table. We weighed the answers, and the data were represented in graphics of categorical variables. Later in November of 2020, when COVID restrictions were reduced for the municipalities, farmers attended a workshop we prepared on cacao waste management. In this space, previous survey results were discussed and confirmed.

\section{Results and Discussion}

\subsection{Cacao Production and Residual Biomass in Colombia}

Cacao world production in 2018/2019 was 4834 million tons of beans, of which $77 \%$ came from Africa, the first world producer, $17 \%$ from the Americas, and $6 \%$ from Oceania [14]. Cacao production is predominantly a cash crop, where more than $90 \%$ of the world's cacao production originates from small farms with 2 to 5 hectares [15]. Colombia occupies the fourth place in Latin America with 59,740 tons for 2018/2019 [14].

Cacao production in Colombia has comparative advantages derived from its geography and location in the tropics. Colombia's climate and soil and cacao trees' ability to grow under agroforestry systems (co-cultivation with other non-cacao crops) help conserve natural diversity by letting different biological systems cooperate and flourish [16-19]. Recently, the economic importance of cacao production, and its vast potential for the internal and external market, has been recognized by the Colombian government. Therefore, in 2020 the Ministry of Agriculture and Rural Development (MADR) promoted the increase of cacao cultivation areas. The cultivation extension also led to a rise in $\mathrm{CPH}$, which could be translated into severe environmental problems if appropriate management is not implemented [20,21]. For example, due to the concave shape of the cacao pod, in rainy seasons, they work as a reservoir of water that facilitates the multiplication of insects, and disease propagation like Moniliophthora roreri and Phytophthora spp., which are the leading cause of economic losses from cacao activity [13,21,22].

Cacao is cultivated in 30 states out of 32 from the total national territory with about 147,000 ha (Figure 1a). The highest production is concentrated in (1) Inter-Andean dry valleys including the departments of Huila, Tolima with 79,663 tons, (2) the Santander mountains, covering the districts of Santander and Norte de Santander with 26,670 tons, (3) the tropical humid forest including Arauca and Meta with 6680 tons, and (4) the low marginal coffee zone: Caldas, Quindio, Risaralda, southwest of Antioquia, with 6607 tons [23] (Figure 1b). 

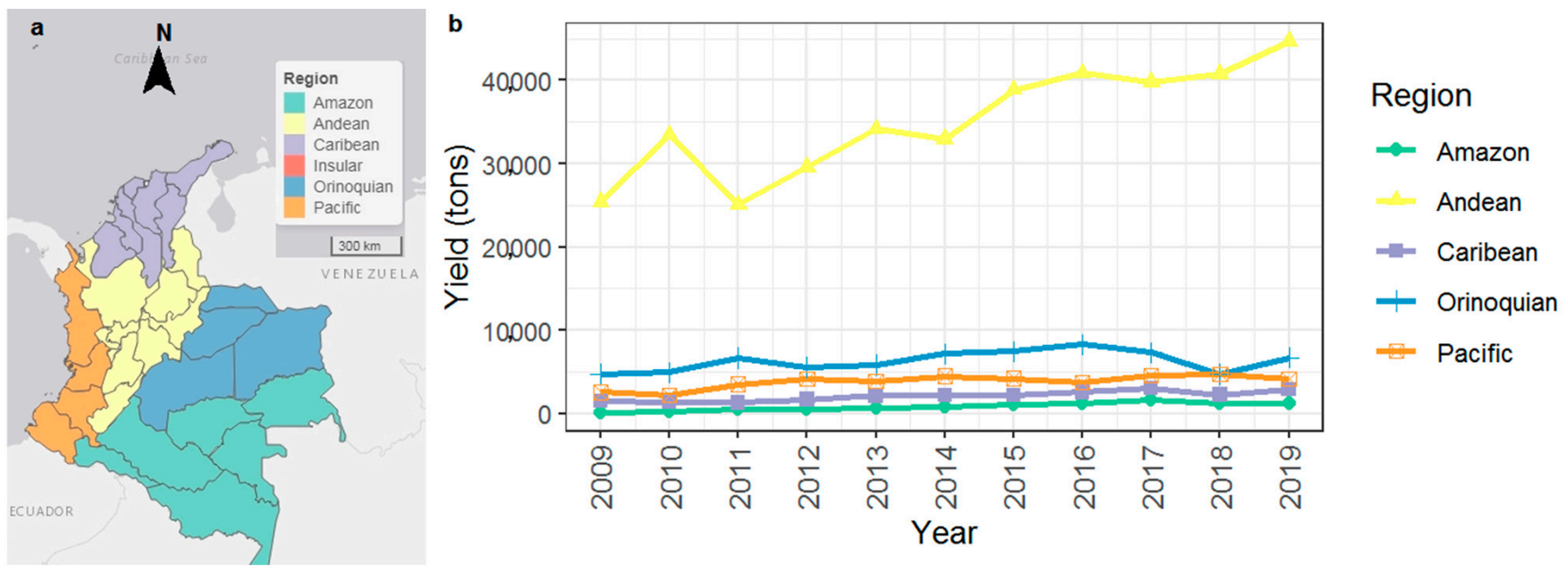

Figure 1. Cacao production according to (a) geographical region, (b) variation from 2009 to 2019. Source [24].

The CPH residual biomass can be roughly calculated based on the national bean production (Figure 2). Variables like bean index (dry bean weight), pod index (number of seeds per pod), and proportion of the $\mathrm{CPH}$ weight in relation to the total pod weight must be considered. To estimate the CPH biomass produced in Colombia for 2019, we considered the above variables weighted for 26 Colombian cacao cultivars [25]. The production for 2019 in the country was 59,740 tons which, divided by the bean index (1.2 g), generates 49,783 million seeds. This value divided by the pod index ( 40 seeds / pod) gives 1244 million pods. This number multiplied by the average pod weight (181.5 $\mathrm{g}$ wet weight) gives 225,891 tons. Finally, this value is multiplied by the proportion of $\mathrm{CPH}$ in the fruit ( $70 \%$ dry weight), giving as a result 189,748 tons in residual biomass only for the year 2019 in Colombia. This results in 3.17 tons of residues per ton of cacao bean produced. Furthermore, considering that from 2009 until 2019, there was an annual increase of about $2.06 \%$ in production for all states in Colombia, we could say that annually 3248 tons of waste are being added to the cacao chain in the country. It could represent a worrying scenario considering that waste management practices are few or non-existent in Colombia.

The $\mathrm{CPH}$ waste value calculated above is underestimated when it is compared to other Colombian reports. Some reports indicate that each ton of dry seed generates about 10 tons of cacao pod husk (fresh weight); meanwhile, other authors report that 79 to $90 \%$ corresponds to the cacao pod's shell [26-29]. Other authors suggest a volume of 2,100,000 tons for 2021 [13]. The authors do not report how those numbers were estimated. Furthermore, differences in the data can relay in humidity percentage, water status (wet or dry cocoa beans, weight per clone, surface and volume per pod, and maturity states). Altogether, it is clear that $\mathrm{CPH}$ waste represents a critical residue because of its large volume and can be used as an important input to valorize.

The increment in cacao production in Colombia is due to the increase in national demand and increased exports. The internal market, which is not entirely supplied, forces the national companies to import cacao [14]. The country's cacao has also been recognized as fine and aroma cacao, thus increasing the exports. For example, in 2019, about 4948 tons were exported to Mexico (54\% of share), followed by Malaysia with $20 \%$, Belgium with $10 \%$, the United States with 5\%, and countries such as Argentina, Holland, and Indonesia representing 3\% of exports [30]. Both the internal and external demand favor an increase in the waste biomass produced, providing an opportunity to develop a robust bio-based economy and add value to this large cacao waste volume. 


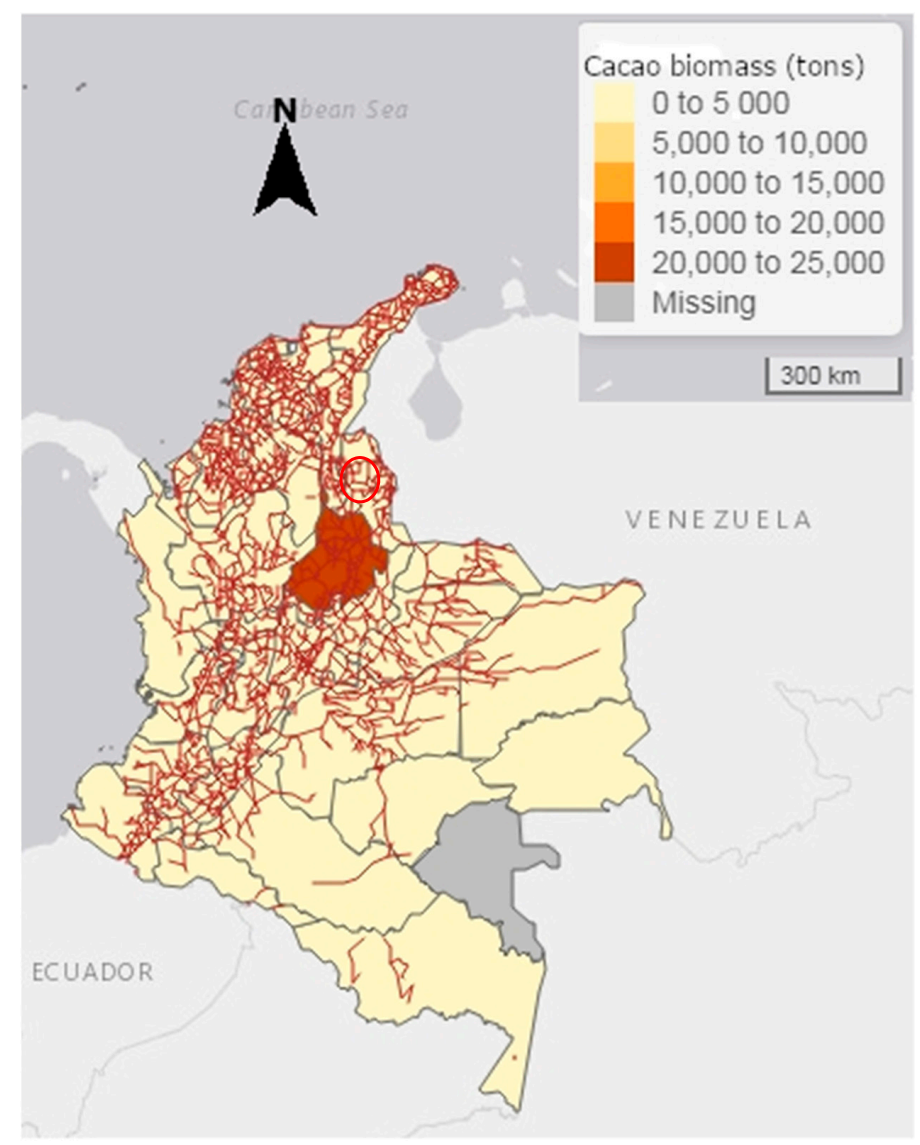

Figure 2. Colombia map representing cacao waste biomass (CPH) in tons based on 2019 beans production and the transport network (red lines). The red circle highlights the Caldas region.

\subsection{Cycle and Characterization of Cacao Pod Husk}

It is essential to valorize the cacao waste to understand when and how the $\mathrm{CPH}$ biomass is formed and its basic chemical composition. $\mathrm{CPH}$ starts to develop at the fruiting stage. Cacao pods are open-pollinated. A cacao pod's growth cycle can usually be divided into three sub-phases: An early accelerating/cell division phase, a linear/cell enlargement phase, and a saturation phase for ripening/maturation, where the growth patterns often follow sigmoid curves [30]. Regarding the pod length, width, surface, and volume, studies have been usually done in African, Malaysian, and Brazilian cultivars [30,31]. On average, a cacao pod has $16.2 \mathrm{~cm}$ in length and $7.88 \mathrm{~cm}$ in width. It takes about 157 days to reach maturity, but it can vary between different genotypes up to 163 days or more.

Furthermore, the time to reach the maximum pod length or width is between 71.9 and 87 days on average. The estimated pod surface areas showed a range from \pm 100 to $610 \mathrm{~cm}^{2}$, with a mean of approximately $330 \mathrm{~cm}^{2}$. Actual pod volumes vary from 100 to 1040 milliliters $(\mathrm{mL})$, and the average is over $500 \mathrm{~mL}$. The authors agree that significant differences are observed between clones [30]. All the above features make CPH a large volume of waste crop compared to the coffee husk (another considerable residue in Colombia) as $\mathrm{CPH}$ occupies more than double of waste per fruit [32].

$\mathrm{CPH}$ makes up $79 \%$ of the fruit weight, and the remaining $21 \%$ of the weight is allocated for beans in the slime and the placenta $[26,27]$. The ear has a rough crust almost $4 \mathrm{~cm}$ thick where it is filled with a thick, sweet, and edible pink pulp [33]. This cacao pod husk comprises three tissues named exocarp, mesocarp, and endocarp [34]. Table 1 presents the ranges and averages calculated for various physicochemical parameters of the $\mathrm{CPH}$. In general, $\mathrm{CPH}$ has a low moisture percentage of about $10 \%$. It contains a good content of fiber $(43 \%)$ and sugars $(45 \%)$ but a low fat content $(0.48 \%)$. It also has a high polyphenol content (21\%) and low alkaloids (theobromine and caffeine) with less than 
$0.4 \mathrm{mg} / 100 \mathrm{~g}$. Regarding the lignocellulosic components, CPH contains 37, 33, 23, and 3\% of hemicellulose, cellulose, lignin, and pectin. In relation with the physical parameters $(\mathrm{pH}$, acidity, calorific value) it is to highlight the calorific value of $\mathrm{CPH}(331 \%)$, which is 12 -fold less compared for example to coffee husk [35].

Table 1. Reports of physicochemical characterization of $\mathrm{CPH}$.

\begin{tabular}{|c|c|c|c|c|}
\hline Parameter & Minimum & Maximum & Average & References \\
\hline$\%$ Moisture & 6.67 & 16.1 & 10.19 & {$[28,36-41]$} \\
\hline$\%$ Volatile material & 49.9 & 68.49 & 59.39 & {$[28,36-38]$} \\
\hline$\%$ Ash & 6.7 & 13.5 & 10.92 & {$[28,36-44]$} \\
\hline$\%$ Fixed carbon & 10.43 & 20.5 & 16.42 & {$[28,36-38]$} \\
\hline Crude protein & 4.21 & 14.63 & 8.55 & {$[39,41,44-46]$} \\
\hline$\%$ Fat & 0.12 & 1.5 & 0.48 & {$[39-41,44]$} \\
\hline$\%$ Fiber & 3.1 & 136.6 & 43.65 & [39-41,45-47] \\
\hline Starch mg/100 g & 2.2 & 2.2 & 2.2 & [45] \\
\hline$\%$ Carbohydrates & 74.93 & 74.93 & 74.93 & {$[39,44]$} \\
\hline Glucose mg/100 g & 1.16 & 1.16 & 1.16 & [46] \\
\hline Sucrose mg/100 g & 0.18 & 0.18 & 0.18 & [46] \\
\hline Total sugars & 45.42 & 45.42 & 45.42 & [41] \\
\hline $\begin{array}{c}\text { Total polyphenols ( } \mathrm{g} / \mathrm{Kg} \\
\text { sample) }\end{array}$ & 21.41 & 21.41 & 21.41 & [41] \\
\hline Caffeine mg/100 g & 0.03 & 0.03 & 0.03 & [47] \\
\hline Tannins mg/100 g & 0.12 & 5.20 & 0.12 & {$[44,47]$} \\
\hline Theobromine $\mathrm{mg} / 100 \mathrm{~g}$ & 0.2 & 0.679 & 0.41 & {$[36,40,44,47]$} \\
\hline Hemicellulose $\mathrm{mg} / 100 \mathrm{~g}$ & 37 & 37 & 37 & [43] \\
\hline Cellulose mg/100 g & 26.1 & 35.4 & 33.02 & {$[43,45,48]$} \\
\hline Lignin mg/100 g & 14.7 & 21.6 & 23.75 & {$[43,45,48]$} \\
\hline Pectin $\mathrm{mg} / 100 \mathrm{~g}$ & 3.71 & 3.71 & 3.71 & [46] \\
\hline $\mathrm{pH}$ & 6.25 & 6.25 & 6.25 & {$[41]$} \\
\hline Titratable acidity & 0.38 & 0.38 & 0.38 & [41] \\
\hline$\%$ Calorific value & 331.31 & 331.31 & 331.31 & [39] \\
\hline
\end{tabular}

Recent studies have shown that pods' developmental age can influence their sensitivity to infection and the severity of the symptoms produced. As cacao pod development and disease sensitivity are closely linked, fungicide applications' timing has also been linked to pod development [30]. Better knowledge of the fruit's development and the chemical composition of $\mathrm{CPH}$ can better inform pest and disease management strategies and define potential bio-products derived from $\mathrm{CPH}$ to be manufactured. Adding value to the cacao waste can bring economic benefits by selling products derived from $\mathrm{CPH}$ or use the products in their farms, reducing the production costs, i.e., mixing the rich-nutrient biomass with chemical fertilizers. Moreover, environmental benefits can be obtained as farmers contribute to close the production process under a circular economy frame.

\subsection{Uses of Cacao Pod Waste}

Sustainably using waste biomass resources to guarantee energy security, mitigate climate change, and satisfy the endless demand for chemicals and materials is a global commitment that can be achieved through waste valorization. Using a biorefinery approach and converting plant biomass to innovative chemical products, energy, and materials can 
replace the needs for oil, coal, natural gas, and other non-renewable energy and chemical sources $[25,49,50]$.

This commitment comes from research institutions and is also promoted by the International Cacao Organization (ICCO), which aims to establish goals among cacao stakeholders to work towards a sustainable world cacao economy. ICCO recognizes the following uses for the CPH such as:

- $\quad$ Food for animals: The fresh fruit is cut and then dried and minced until obtaining granules that are used as animal food [51];

- $\quad$ Mild soap making: The ash from the cacao pod shell is mainly used for making mild soap. The fresh husks are spread out in the open air to dry for one or two weeks to prepare the ash. The dried shells are then incinerated in an incineration oven [51];

- $\quad$ Fertilizer for cacao, vegetables, and food crops [51].

In general, the investigations in uses of $\mathrm{CPH}$ are reported from high cacao-producing regions, reflecting a direct relationship between the increase in waste and the need to identify possible uses of this. For example, the African continent, the largest worldwide producer (especially Ivory Coast, Ghana, Cameroon, and Nigeria), reports the most significant scientific publications related to the $\mathrm{CPH}$ and its uses. With less intensity, the investigations in $\mathrm{CPH}$ are followed by Latin American cacao producers like Ecuador, Brazil, Peru, Mexico, and Colombia [52]. The primary reported uses for $\mathrm{CPH}$ are categorized into three uses: Energy, food, and miscellaneous.

\subsubsection{Energy Uses for Cacao Residues}

The research focused on bioenergy generated from $\mathrm{CPH}$ highlights the use of $\mathrm{CPH}$ as green solid base catalysts for the trans-esterification of soybean oil in biodiesel [53] or as a new source of hydrolase enzymes for the preparation of cross-linked enzymatic aggregate for bioenergy [54]; as a new source of CLEA-lipase for the preparation of low-cost biodiesel [54]; in poultry manure for energy generation through liquefaction [55,56]; or in biogas production by anaerobic digestion [57].

Studies carried out in Africa report the use of $\mathrm{CPH}$ as a base catalyst for the transesterification of Hevea brasiliensis oil (HBO) to the methyl ester of Hevea brasiliensis (HBME) in Nigeria [58]. Other authors in Ghana report the production and characterization of $\mathrm{CPH}$ as briquettes and sawdust for bioenergy [59].

In Latin America, studies from Ecuador report the CPH use as a binder material for pellets [60] and elaborate biochar [61]. In Colombia, a few studies reported the use of CPH as a source of renewable energy [13] and as a source to obtain activated carbon as energy storage [62]. These studies indicate varied efforts to demonstrate the CPH potential in life uses, but a clear major or commercial use is not currently available.

\subsubsection{Food Uses for Cacao Residues}

Possible uses have been identified from the academy for $\mathrm{CPH}$. They include improved antioxidants like vitamin C [63]. Other research highlights $\mathrm{CPH}$ as a valuable source of antioxidant food materials rich in dietary fiber that can be used to significantly reduce the risk of development of various free radical-induced diseases [64].

In 2018, a study in Ghana reported the use of CPH in animal feed, which is improved by a low content of theobromine [65]. A Colombian study describes CPH as a flour source of the CCN-51 variety [39]. The above results highlight the diverse uses of CPH due to its metabolic richness, mainly in fiber. Again, commercial developments are still lacking.

\subsubsection{Miscellaneous Uses for Cacao Residues}

$\mathrm{CPH}$ is a rich source of minerals, lignocellulosic components, and antioxidants [66]. This varied composition has allowed $\mathrm{CPH}$ to be used in different fields [67]. For example, $\mathrm{CPH}$ has demonstrated benefits as a soil improver [68,69], and due to its high potassium content, it has been dedicated to producing potassium carbonate [70] or as potassium fertilizer in the growth of cacao seedlings [71]. The high lignocellulosic content in CPH can 
be used to produce carboxymethylcellulose. It is a liquid loss control agent utilized under high temperatures and differential pressure conditions [72].

Studies in Latin America vary from country to country. For example, one study from the Huila region, the fourth-largest producer in Colombia, tested the effect of the dumping of the byproducts from $\mathrm{CPH}$ in the soil with interesting chemical and biological properties in a cacao farm $[17,26]$. Other Colombian investigations have proposed using $\mathrm{CPH}$ as a partial substitute for the polymeric matrix in obtaining polyurethane foams [73] and as a biocomposite and polypropylene source, the latest performed in the Santander region [74]. Venezuela recognizes the potential of $\mathrm{CPH}$ to generate new pharmaceutical, medical, nutraceutical, or functional food products through fermentation, enzymatic hydrolysis, and combustion, among others [75]. In Mexico, $\mathrm{CPH}$ has been tested as a pectin production source throughout the supercritical fluid technique [76].

Additionally, the effects of microwaves, hot air, and lyophilization on phenolic compounds, antioxidant capacity, enzymatic activity, and microstructure of $\mathrm{CPH}$ have been tested [77]. In Brazil, investigations are also related to pectin extraction from $\mathrm{CPH}$ with gelling functions [78-80]. In the same line of stabilizers, another study reports $\mathrm{CPH}$ use to produce xanthan gum production using Xanthomonas campestris strains over cacao shell residues [81]. In Ecuador, the determination of kinetic parameters in the devolatilization of residual biomass has been reported [28].

Furthermore, research has been carried out comparing different types of biomass in solid substrate fermentation using wastes such as $\mathrm{CPH}$, cassava husk (CP), and palm kernel cake (PKC) for the production of fructosyltransferase (FTase) by the fungal strain Rhizopus stolonifer [82]. In addition, through solid-state fermentation of $\mathrm{CPH}$, the quality of agricultural waste has been improved and used for soil fertilizers. Finally, a particular use of $\mathrm{CPH}$ has been reported in cosmetology for anti-wrinkling on human skin surfaces [83].

In recent years, several studies have emerged to define strategies for the valorization of $\mathrm{CPH}$. However, we do not perceive a concrete materialization of the above-mentioned $\mathrm{CPH}$-based products into the cacao value chain through the literate research, at least in the Colombian context. What is lacking to fill the gap from the biomass to the final product is an aim we are planning to address through BBVC implementation. Furthermore, we recognize all the research efforts in $\mathrm{CPH}$ raise the attention to this residue, highlighting the importance of adding value to this large waste volume to provide a more sustainable bioeconomy of the cacao value chain in Colombia.

From this literature review, we found that Colombia has significant potential in terms of residual biomass. For instance, about 189,748 tons of CPH were estimated based on the national production for 2019. This biomass increases annually due to plantation to new areas and rises in the crop yield. According to the literature review, we identified that, in general, Colombia is venturing into the use of the $\mathrm{CPH}$ mainly for fertilizers source. In contrast, worldwide, $\mathrm{CPH}$ uses have already been identified for energy, food, cosmetics, and pharmaceuticals. However, an identified limitation for $\mathrm{CPH}$ is the absence of a defined product marketing process, since most of the products derived from $\mathrm{CPH}$ are in the research and incipient development stage, which opens an exciting spectrum for Colombian new markets. Finally, this scenario imposes a big challenge in potentiating those $\mathrm{CPH}$ uses in a research state and converting them into a tangible product that could be marketing.

\subsection{Farmers Socioeconomics and Waste Management from Caldas Region in Colombia}

Analysis of socioeconomic variables suggested that cacao is a cash crop mainly cultivated by small farmers of Caldas state whose land is less than 5 ha (Figure 3a). Cacao farmers also tend to grow cacao in combination with other crops (Figure $3 \mathrm{~b}$ ). In Colombia, cacao producers typically establish and manage their cacao plantations under shade using various configurations depending upon climate, soils, household food needs, and potential for generating income. These arrangements tend to include banana plants, fruit trees, and taller shade trees. When planned appropriately, this agroecological setting can become advantageous under climate change scenarios as farmers can quickly introduce new crops 
that are more resilient to erratic weather patterns. However, informal conversations with farmers during the workshops suggested that farmers have used the same agronomic practices over generations. Traditionally, small farmers such as those in this survey have no access to decision support systems to optimize their crop management. Therefore, crop yield tends to be suboptimal due to the many factors affecting it, such as diseases, poor soils, bad weather, and wrong harvest time. The workshop also highlighted the absence of feedback between farmers and cacao associations. Cacao is cleaned and sometimes processed, depending on the overall cacao production's size and quality for a particular region. Feedback is essential not only to farmers but to other stakeholders as it can be used to identify and correct factors affecting the yield.

\subsection{Farmers' Attitude towards the Management of Agricultural Waste}

Before the workshop, we asked farmers by phone calls about their knowledge on methods to manage cacao waste. The majority of farmers did not know what to do with the residues (Figure 3c), apart from the idea of using them as fertilizers (Figure 3d), although they did not realize how to process them. Thus, most farmers leave their cacao waste in the field or burn it; only one farmer used it as fertilizer but stopped the practice after a few attempts because it demanded more labor. Since they have not received training on waste management (Figure 3e), they lack the knowledge to re-use the cacao waste as fertilizer. Extension services focused on waste management are a real bottleneck for agricultural innovation in Colombia. They are sparse, disconnected from R\&D; the technical assistants lack the required skills to manage $\mathrm{CPH}$ and need specific training.

However, after the workshop on cacao waste management, farmers showed an extraordinary interest in learning how to get involved in cacao waste processing for agricultural and industrial usages (Figure 3f). Farmers also showed great concern about protecting the environment. They are incredibly aware of the somewhat erratic climate changes in the Caldas region, where dry and hotter days are becoming more frequent, and want to take action before it is too late. 
a

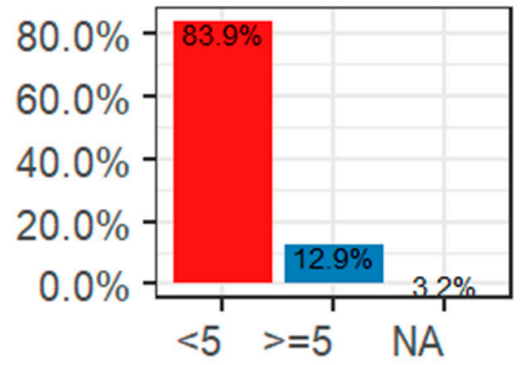

Cacao area cultivated (ha)

C

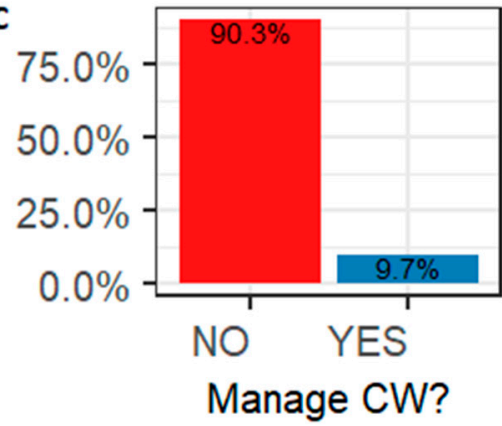

e

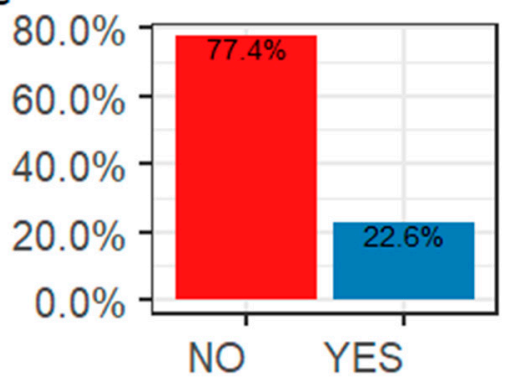

Received training on $\mathrm{CW}$ management answer

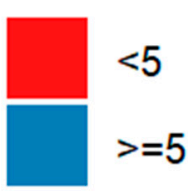

NA

b

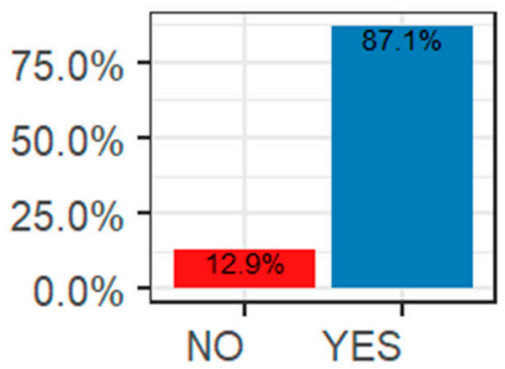

answer

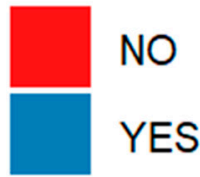

Mutiple crops

d

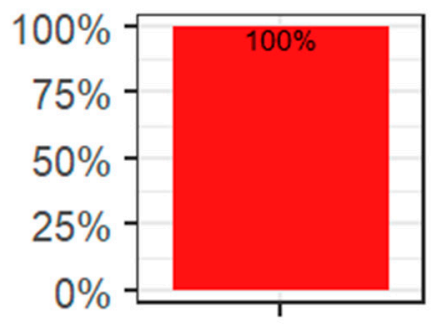

answer

NO

YES
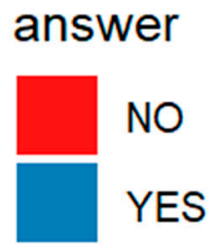

Known CW by-products

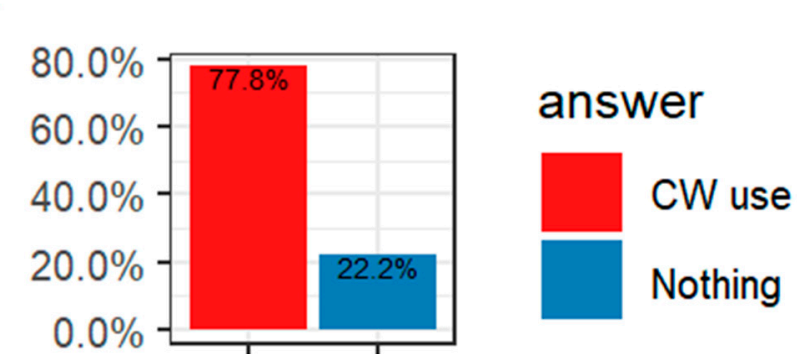

$\mathrm{CW}$ useNothing

Encourages farmer to manage $\mathrm{CW}$

Figure 3. Analytics on data collected through farmers' surveys and workshops. CW: Cacao waste; NA: Not applicable.

\subsection{Strategy to Implement a BBVC from the Cacao Production in Colombia}

A typical cacao bean value chain (CVC) system involves the operation of five major segments-cacao bean production known as primary processing, followed by sourcing and marketing, processing of powder and butter, manufacturing and distribution of industrial chocolate, and retailing to the final consumers. All of the above are known as secondary processing. The main stakeholders comprise cacao producers, marketers of cacao, cacao processors, chocolate manufacturers, and retailers [84]. Interestingly, primary and secondary processes also retain a significant division in the cacao value chain regarding geographical location and technical characteristics. For example, only eight worldwide traders and grinders control approximately three-quarters of the global cacao trade. Few companies like Mars, Molendéz International, Nestlé, Hershey's, and Ferrero accounted for $88 \%$ of the confectionery market in 2012, most of them located in the north hemisphere. The scenario is the same in Colombia, with the Compañía Nacional de Chocolates and Luker controlling about 80 and $90 \%$ of the National production. Other food manufacturer representations are from: Colombina S.A. (4\%); Andean Chocolate (3\%); Gironés Chocolate $(2 \%)$; Comestibles Italo (1\%); and other small processors share the remaining $10 \%$ [16].

Cacao farmers are primarily from developing countries, where they earn less than USD 1 per day. Thus, only $6 \%$ of the value distribution goes to the producers, whereas the other $94 \%$ is divided among the actors implementing the secondary processing and distribution. Additionally, cacao farmers daily struggle with all the risks related to weather, 
diseases, other environmental variables, and international price fluctuation. This scenario evidences an uneven value distribution. Furthermore, as the cacao's economic value is not generated by the raw material, almost the final product revenue's totality goes to the distributors, usually operating in big consumer countries. Under this scenario, farmers are not actively involved in the cacao value chain's balance of power [85].

An important aspect to highlight in the CVC is that the farmers contribute considerably to the actual bean quality. It could be said that $70 \%$ of the quality of cacao does not depend so much on environmental variables but on farmers' actions [85]. The crop maintenance, the harvesting timing and technique, and specific first processing activities such as fermentation and drying strongly determine the quality. If these delicate activities are not carried out correctly, it is not possible to enhance the final product's quality during the following stages [85]. Therefore, promoting training projects for cacao farmers in added-value practices at the primary processing would make a difference to shift the economic balance in the CVC, favoring farmers' incomes.

In most bioeconomy settings, feedstocks tend to come from biomass drew from an existing primary production route (e.g., agriculture, forestry, and livestock) or a novel (e.g., microalgae) or secondary origin (e.g., sludge, industrial wastewater, and household organic waste) [86]. The added value to CPH depends on the supply, transportation, transformation technology, and final use, which can vary depending on the context. Thus, the successful development of a BBVC for cacao relies on identifying technical, social, environmental, and economic conditions adjusted to a particular region, allowing the techno-economic feasibility to be determined for a promising bio-based product(s). Part of the future work of this project is to carry out techno-economic assessments that include (1) evaluation of the spatial availability of the agricultural residue biomass in the area, (2) description of the list of potential production farm sites for the conversion of the residues, (3) definition of data and methods for waste conversion, (4) investment costs and cost estimates of residues conversion, and, finally, (5) determination of the economic feasibility of a targeted promising bioproduct and (6) a description of the prioritized bio-based value chain for the Caldas region.

Through the literature review, we identified a large diversity on possible uses of $\mathrm{CPH}$. However, these uses are dependent on the chemical composition of $\mathrm{CPH}$. Thus, a systematic characterization of the $\mathrm{CPH}$, particularly from Caldas, is necessary. Furthermore, to adjust the prioritization of a product derived from $\mathrm{CPH}$ in a particular region, it is essential to include the farmer's perspective into any product development. They know the context better and can help address the type of products developed in the region.

As we evidenced the famer's lack of knowledge in waste management practices, a future strategy should aim to support farmers with the knowledge they need to start adding value to their residual biomass as they are the first line of stakeholders handling the residues. It could be necessary to include specialized training in waste management for cacao for farmers.

\section{Challenges and Perspectives}

The Colombian Low Carbon Development Strategy recognizes that although Colombia's carbon emissions are low relative to developed countries, they will grow significantly if no mitigation occurs. Considering the projected economic growth in agriculture in Colombia, an equal proportion of agricultural residues and greenhouse emissions will also be generated. In cacao production, a large proportion of $\mathrm{CPH}$ burns or is untreated on the field. Therefore, the use of BBVC is the best solution to manage that valuable biomass.

Research on $\mathrm{CPH}$ management is growing, and some studies show that $\mathrm{CPH}$ can be a viable alternative for transforming this residual biomass into fine products [44,75]. $\mathrm{CPH}$ is currently used to a limited extent in the energy and food industry with minor uses in other industries like cosmetics. In addition, there are no collection methods at harvest, and farmers consider them as waste [28]. In Colombia, CPH is not re-used or transformed because, as noted by surveys and workshops, farmers do not know how to proceed. There 
is also a lack of information on what biomass strategies to use, when, and how. To valorize cacao waste in Colombia, it is necessary to perform a complete characterization of $\mathrm{CPH}$ and determine uses mainly by geographic area. Our future work aims to develop this characterization, starting with the Caldas area and rolling out to the entirety of Colombia. We believe this process could be replicated for other cash-important crops in Colombia such as coffee, banana, and flowers, which also generate significant residues. It is a timely moment to develop BBVC.

Finally, the proposed strategy strives to exchange knowledge with cacao farmers and associations in the Caldas region. Dissemination activities are planned due to an allies' network working in cacao. The activities are thought to engage growers, entrepreneurs, researchers, and non-specialized communities towards "zero-waste" awareness and show the importance of developing BBVC. We consider that the progress in bioeconomy can be accelerated by sharing knowledge and involving the community in the decision-making, allowing the farmers to be the protagonist in this BBVC.

\section{Conclusions}

Given the increase in agricultural residues due to higher demands for food, energy, and goods, the development of context-specific BBVC from agricultural residues is needed. This strategy will reduce environmental pollution and transform the residues generated by farmers into added-value products to supply the local demands under the concept of a sustainable bioeconomy.

This paper reported state-of-the-art CPH management in Colombia and worldwide. We found that most of the studies reviewed here were not stratified by cacao variety or geographic region, limiting the reproducibility of the studies and their implementation in the cacao supply chain. The majority of reports also failed to analyze the potential commercial impact or direct market application of their CPHs management strategies. We believe that the absence of success indicators is due to the lack of clearly identified social, economic, and environmental factors affecting the development of a BBVC for a particular region. A possible solution to measure technological success indicators, from "waste to the market", is to carry out techno-economic assessments for a prioritized bioproduct from $\mathrm{CPH}$ promoting a circular economy. For example, in this project, we targeted the Caldas region in which $\mathrm{BBCV}$ strategies to manage $\mathrm{CPH}$ will be researched, evaluated, tested, and rolled out.

Supplementary Materials: The following are available online at https:/ /www.mdpi.com/article/10 .3390/agronomy11040693/s1, Supplementary File 1: Survey questionnaire.

Author Contributions: Conceptualization, A.V.C.-R. and A.M.G.; survey data collection, D.C.M.-S.; D.C.M.-S., A.V.C.-R. and A.M.G.; writing-original draft preparation, D.C.M.-S., A.V.C.-R., and A.M.G.; data analysis, A.V.C.-R.; review and editing A.M.C., A.Z., and J.W.A. All authors have read and agreed to the published version of the manuscript.

Funding: This research was funded by the Ministry of Science and Technology of Colombia and Newton Fund, UK in the Call Institutional Links, Unique ID of the project 527661158.

Institutional Review Board Statement: Not applicable.

Informed Consent Statement: Informed consent was obtained from all subjects involved in the study.

Acknowledgments: We thank Asoprobel for their help in the cacao farmers' survey process in Caldas state.

Conflicts of Interest: The authors declare no conflict of interest. 


\section{References}

1. Zorb, C.; Lewandowski, I. Biobased resources and value chains. In Bioeconomy: Shaping the Transition to a Sustainable, Biobased Economy; Springer: Berlin/Heidelberg, Germany, 2018; ISBN 9783319681511.

2. Inyinbor, A.A.; Oluyori, A.P.; Adelani-Akande, T.A. Biomass Valorization: Agricultural Waste in Environmental Protection, Phytomedicine and Biofuel Production. In Biomass Volume Estimation and Valorization for Energy; InTech: London, UK, 2017; pp. 99-121.

3. FAO El Desarrollo Sostenible. Available online: http://www.fao.org/3/x5600s/x5600s05.htm (accessed on 17 September 2020).

4. Smil, V. Crop Residues: Agriculture's Largest Harvest. Alzheimers Dement. 1999, 49, 299-308. [CrossRef]

5. Escalante Hernández, H.; Orduz Prada, J.; Zapata Lesmes, H.J.; Cardona Ruiz, M.C.; Ortega, M.D. Atlas del Potencial Energético de la Biomasa Residual en Colombia; Universidad Industrial de Santander: Bucaramanga, Colombia, 2013; Volume 1.

6. Scarlat, N.; Martinov, M.; Dallemand, J.F. Assessment of the availability of agricultural crop residues in the European Union: Potential and limitations for bioenergy use. Waste Manag. 2010, 30, 1889-1897. [CrossRef]

7. DNP. Política de Crecimiento Verde (Documentos CONPES 3934); DNP: Bogotá, Colombia, 2018.

8. Tonini, D.; Albizzati, P.F.; Fruergaard Astrup, T. Environmental impacts of food waste: Learnings and challenges from a case study on UK. Waste Manag. 2018, 76, 744-766. [CrossRef] [PubMed]

9. Andini, A.; Bonnet, S.; Rousset, P.; Hasanudin, U. Impact of open burning of crop residues on air pollution and climate change in Indonesia. Curr. Sci. 2018, 115, 2259-2266. [CrossRef]

10. Devi, S.; Gupta, C.; Jat, S.L.; Parmar, M.S. Crop residue recycling for economic and environmental sustainability: The case of India. Open Agric. 2017, 2, 486-494. [CrossRef]

11. Kumar, H.; Remote, P.; Centre, S. Crop Residue Burning: Impacts on Air Quality, Health and Climate Change Modelling using Geospatial Technology: A Review. Int. J. Creat. Res. Thoughts 2018, 6, 524-534. [CrossRef]

12. Ramya, R.; Devi, S.; Manikandan, A.; Kannan, V.R. Standardization of biopolymer production from seaweed associative bacteria. Int. J. Biol. Macromol. 2017, 102, 550-564. [CrossRef]

13. Martínez-Ángel, J.D.; Villamizar-Gallardo, A.; Ortiz-Rodríguez, O.O. Characterization and evaluation of cacao (Theobroma cacao L.) pod husk as a renewable energy source. Agrociencia 2015, 49, 329-345.

14. Fedecacao. Federación Nacional de Cacaoteros El Cacaocultor es lo Primero Economía Internacional. Available online: https: / / www.fedecacao.com.co/portal/index.php/es/2015-02-12-17-20-59/nacionales (accessed on 6 October 2020).

15. ICCO International Cacao Organization. Available online: https://www.icco.org/about-cacao/chocolate-industry.html (accessed on 22 September 2020).

16. Espinal, C.F.; Martínez, H.J.; Ortíz, L. La cadena del cacao en Colombia una mirada global de su estructura y dinámica 1991-2005 Documento de Trabajo No. 58. Minist. Agric. y Desarro. Rural. Obs. Agrocadenas Colomb. 2005, 51, 1.

17. Ortiz, K.; Álvarez, R. Efecto del Vertimiento de (Theobroma cacao L.) sobre algunas propiedades quimicas y biológicas en los suelos de una finca cacaotera, Municipio de Yaguara (Huila, Colombia). Boletín Científico Cent. Mus. Mus. Hist. Nat. 2015, 19, 65-84. [CrossRef]

18. Ministerio de Agricultura y Desarrollo Rural. Área Sembrada, Área Cosechada, Producción y Rendimiento del Cultivo 2014; Ministerio de Agricultura y Desarrollo Rural: Bogotá, Colombia, 2014.

19. Ministerio de Agricultura y Desarrollo Rural. Informe de Rendición de Cuentas 2016-2017 El Renacer del Campo; Ministerio de Agricultura y Desarrollo Rural: Bogotá, Colombia, 2017.

20. Perez, M.I.; Peñaranda, L.F.; Herazo, M.M. Impacto, Manejo y Control de Enfermedades Causadas por Phytophthora Palmivora en Diferentes Cultivos; Universidad de Pamplona: Norte de Santander, Colombia, 2010.

21. Rojas, F.; Sacristán, E.J. Guía Ambiental Para el Cultivo del Cacao; Peinado, J.E., Ed.; FEDECACAO: Bogotá, Colombia, 2013.

22. Barraza, F.; Schreck, E.; Lévêque, T.; Uzu, G.; López, F.; Ruales, J.; Prunier, J.; Marquet, A.; Maurice, L. Cadmium bioaccumulation and gastric bioaccessibility in cacao: A field study in areas impacted by oil activities in Ecuador. Environ. Pollut. 2017, 229, 950-963. [CrossRef]

23. Superintendencia de industria y comecio. Cadena Productiva del Cacao: Diagnostico de Libre Competencia; Superintendencia Industria y Comercio: Bogota, Colombia, 2011; pp. 1-6.

24. Fedecacao. Federación Nacional de Cacaoteros Boletín de prensa-Así quedó el ranking de producción de cacao en Colombia. Available online: http:/ / www.fedecacao.com.co/portal/index.php/es/2015-04-23-20-00-33/1193-boletin-de-prensa-asi-quedoel-ranking-de-produccion-de-cacao-en-colombia\%0Ahttps://www.fedecacao.com.co/portal/index.php/es/2015-04-23-2000-33/1193-boletin-de-prensa-asi-quedo-el-ran (accessed on 10 September 2020).

25. Perea, A.; Martínez Guerrero, N.; Aranzazu Hernández, F.; Cadena, T. Caracteristicas de Calidad del Cacao de Colombia; Universidad Industrial de Santander: Bucaramanga, Colombia, 2013; ISBN 9789588915227.

26. Mejía, L.A.; Argüello, O. Tecnología Para el Sistema de Producción de Cacao; Corporación Colombiana de Investigación Agropecuaria, CORPOICA: Bucaramanga, Colombia, 2000.

27. Torres Cabezas, M.A. Obtención de Celulosa a Partir de la Cáscara de Cacao Ecuatoriano (Theobroma cacao L.) Mediante Hidrólisis Térmica Para la Elaboración de Pulpa de Papel; Universidad Central del Ecuador: Quito, Ecuador, 2019; Volume 6.

28. Orjuela, W.A.; Cardona, E.A.; Murillo, W.; Méndez, J.J. Aprovechamiento de la Biomasa Lignocelulósica de la Cadena del Cacao, UN Camino a la Bioeconomia Circular; Universidad del Tolima: Ibague, Colombia, 2019; pp. 1-20. 
29. Encalada, J.; Jácome, T. Determinación de Parámetros Cinéticos en la Devolatilización de Biomasa Residual de Cacao Ecuatoriano; Universidad Central de Ecuador: Quito, Ecuador, 2018; Volume 10.

30. Ten Hoopen, G.M.; Deberdt, P.; Mbenoun, M.; Cilas, C. Modelling cacao pod growth: Implications for disease control. Ann. Appl. Biol. 2012, 160, 260-272. [CrossRef]

31. Daymond, A.J.; Hadley, P. Differential effects of temperature on fruit development and bean quality of contrasting genotypes of cacao (Theobroma cacao). Ann. Appl. Biol. 2008, 153, 175-185. [CrossRef]

32. Oliveira, L.S.; Franca, A.S. An Overview of the Potential Uses for Coffee Husks; Elsevier Inc.: Amsterdam, The Netherlands, 2015; ISBN 9780124167162.

33. Franco, M.; Ramírez, M.; García, R.; Bernal, M.; Espinosa, B.; Solís, J.; Durán, C. Reaprovechamiento Integral de Residuos Agroindustriales: Cáscara y Pulpa de Cacao para la Producción de Pectinas. Rev. Lat. Ambiente Cienc. 2010, 1, 45-66.

34. Guevara, J. The Chocolate Fruit: Looking Inside a Cacao Pod. Available online: https://perfectdailygrind.com/2018/02/ chocolate-fruit-looking-inside-cacao-pod/ (accessed on 10 September 2020).

35. Sisbudi Harsono, S. Coffee Husk Biopellet Characteristics as Solid Fuel for Combustion Stove. Environ. Sci. Curr. Res. 2019, 2, 1-6. [CrossRef]

36. Syamsiro, M.; Saptoadi, H.; Tambunan, B.H. Experimental investigation on combustion of bio-pellets from Indonesian Cacao Pod Husk. Asian J. Appl. Sci. 2011, 4, 712-719. [CrossRef]

37. Titiloye, J.O.; Abu Bakar, M.S.; Odetoye, T.E. Thermochemical characterisation of agricultural wastes from West Africa. Ind. Crops Prod. 2013, 47, 199-203. [CrossRef]

38. Forero-Nuñez, C.A.; Jochum, J.; Vargas, F.E.S. Effect of particle size and addition of cacao pod husk on the properties of sawdust and coal pellets. Ing. Investig. 2015, 35, 17-23. [CrossRef]

39. Villamizar, Y.L.; Rodriguez, J.S.; León, L.C. Caracterización fisicoquímica, microbiológica y funcional de harina de cáscara de cacao (Theobroma cacao L.) variedad CCN-51. Cuad. Act. 2017, 9, 65-75.

40. Nguyen, V.T.; Nguyen, N.H. Proximate Composition, Extraction, and Purification of Theobromine from Cacao Pod Husk (Theobroma cacao L.). Technologies 2017, 5, 14. [CrossRef]

41. Castillo, E.; Alvarez, C.; Contreras, Y. Caracterización fisicoquímica de la cáscara del fruto de un clon de cacao (Theobroma cacao L.) Cosechados en Caucagua, estado Miranda. Venezuela. Rev. Invest. 2018, 42, 154-176.

42. Njoku, V.O.; Ayuk, A.A.; Ejike, E.E.; Oguzie, E.E.; Duru, C.E.; Bello, O.S. Cacao pod husk as a low cost biosorbent for the removal of $\mathrm{Pb}(\mathrm{II})$ and $\mathrm{Cu}(\mathrm{II})$ from aqueous solutions. Aust. J. Basic Appl. Sci. 2011, 5, 101-110.

43. Daud, Z.; Awang, H.; Mohd Kassim, A.S.; Mohd Hatta, M.Z.; Mohd Aripin, A. Cacao Pod Husk and Corn Stalk: Alternative Paper Fibres Study on Chemical Characterization and Morphological Structures. Adv. Mater. Res. 2014, 911, 331-335. [CrossRef]

44. Vásquez, Z.S.; de Carvalho Neto, D.P.; Pereira, G.V.M.; Vandenberghe, L.P.S.; de Oliveira, P.Z.; Tiburcio, P.B.; Rogez, H.L.G.; Góes Neto, A.; Soccol, C.R. Biotechnological approaches for cacao waste management: A review. Waste Manag. 2019, 90, 72-83. [CrossRef] [PubMed]

45. Alemawor, F.; Dzogbefia, V.P.; Oddoye, E.O.K.; Oldham, J.H. Enzyme cocktail for enhancing poultry utilisation of cacao pod husk. Sci. Res. Essay 2009, 4, 555-559.

46. Daniyan, I.A.; Adeodu, A.O.; Adewumi, D.F. Design of a Processor for the Production of 30,000 Tons of Caustic Potash per Anum from Cacao Pod. Int. J. Sci. Res. 2014, 3, 691-700.

47. Adeyeye, S.A.; Ayodele, S.O.; Oloruntola, O.D.; Agbede, J.O. Processed cacao pod husk dietary inclusion: Effects on the performance, carcass, haematogram, biochemical indices, antioxidant enzyme and histology of the liver and kidney in broiler chicken. Bull. Natl. Res. Cent. 2019, 8. [CrossRef]

48. García Torres, A.M.; Torres Sáe, R.G. Producción de enzimas lignolíticas por Basidiomycetes mediante la técnica de fermentación en sustrato sólido. Rev. Colomb. Biotecnol. 2003, 1, 56-64.

49. Diep, N.Q.; Sakanishi, K.; Nakagoshi, N.; Fujimoto, S.; Minowa, T.; Xuan, T.D. Biorefinery: Concepts, Current Status, and Development Trends. Int. J. Ofbiomass Renew. 2012, 1, 1-8.

50. Wang, M.; Cao, W.; Sun, C.; Sun, Z.; Miao, Y.; Liu, M.; Zhang, Z.; Xie, Y.; Wang, X.; Hu, S.; et al. To distinguish the primary characteristics of agro-waste biomass by the principal component analysis: An investigation in East China. Waste Manag. 2019, 90, 100-120. [CrossRef] [PubMed]

51. ICCO International Cacao Organization (ICCO). Available online: http://www.icco.org/about-us/international-cacaoagreements / cat_view/30-related-documents/46-statistics-production.html (accessed on 6 October 2020).

52. Abbott, P.C.; Benjamin, T.J.; Burniske, G.R.; Croft, M.M.; Fenton, M.; Kelly, C.R.; Lundy, M.; Rodriguez Camayo, F.; Wilcox, M., Jr. An Analysis of the Supply Chain of Cacao in Colombia; United States Agency for International Development: Washington, DC, USA, 2019.

53. Ofori-Boateng, C.; Lee, K.T. The potential of using cacao pod husks as green solid base catalysts for the transesterification of soybean oil into biodiesel: Effects of biodiesel on engine performance. Chem. Eng. J. 2013, 220, 395-401. [CrossRef]

54. Khanahmadi, S.; Yusof, F.; Chyuan Ong, H.; Amid, A.; Shah, H. Cacao pod husk: A new source of CLEA-lipase for preparation of low-cost biodiesel: An optimized process. J. Biotechnol. 2016, 231, 95-105. [CrossRef]

55. Dahunsi, S.O.; Osueke, C.O.; Olayanju, T.M.A.; Lawal, A.I. Co-digestion of Theobroma cacao (Cacao) pod husk and poultry manure for energy generation: Effects of pretreatment methods. Bioresour. Technol. 2019, 283, 229-241. [CrossRef] [PubMed] 
56. Dahunsi, S.O.; Adesulu-Dahunsi, A.T.; Izebere, J.O. Cleaner energy through liquefaction of Cacao (Theobroma cacao) pod husk: Pretreatment and process optimization. J. Clean. Prod. 2019, 226, 578-588. [CrossRef]

57. Hermansyah, H.; Fedrizal, F.F.; Wijanarko, A.; Sahlan, M.; Utami, T.S.; Arbianti, R. Biogas production from co-digestion of cacao pod husk and cow manure with cow rumen fluid as inoculum. In Proceedings of the International Conference on Trends in Material Science and Inventive Materials, Coimbatore, India, 9-10 April 2020.

58. Adepoju, T.F.; Olatunji, O.M.; Ibeh, M.A.; Kamoru, A.S.; Olatunbosun, B.E.; Asuquo, A.J. Heavea brasiliensis (Rubber seed): An alternative source of renewable energy. Sci. Afr. 2020, 8, e00339. [CrossRef]

59. Ofori, P.; Akoto, O. Production and Characterisation of Briquettes from Carbonised Cacao Pod Husk and Sawdust. Open Access Libr. J. 2020, 7, 1-20. [CrossRef]

60. Velazquez-Araque, L.; Cárdenas, J. Study of influence of starch as binder material for Ecuadorian cacao pod husk pellets. In Proceedings of the WMSCI 2017-21st World Multi-Conference on Systemics, Cybernetics and Informatics, Orlando, FL, USA, 8-11 July 2017; Volume 1, pp. 373-377.

61. Campoverde, J.F. Elaboración de Biocarbón Obtenido a Partir de la Cáscara del Cacao y Raquis del Banano; Universidad de Machala: Machala, Ecuador, 2019.

62. Valencia, A. Obtención de Carbón Activado a Partir de la Cáscara de Mazorca de Theobroma cacao L. de la Granja Gilberto Peláez Ángel del Corregimiento de Combia Risaralda; Universidad tecnológica de Pereira: Pereira, Colombia, 2018.

63. Sakagami, H.; Satoh, K.; Fukamachi, H.; Ikarashi, T.; Shimizu, A.; Yano, K.; Kanamoto, T.; Terakubo, S.; Nakashima, H.; Hasegawa, H.; et al. Anti-HIV and vitamin C-synergized radical scavenging activity of cacao husk lignin fraction. Vivo (Brooklyn) 2008, 22, 327-332.

64. Yapo, B.M.; Besson, V.; Koubala, B.B.; Koffi, K.L. Adding Value to Cacao Pod Husks as a Potential Antioxidant-Dietary Fiber Source. Am. J. Food Nutr. 2013, 1, 38-46. [CrossRef]

65. Oduro-Mensah, D.; Ocloo, A.; Lowor, S.T.; Bonney, E.Y.; Okine, L.K.N.A.; Adamafio, N.A. Isolation and characterisation of theobromine-degrading filamentous fungi. Microbiol. Res. 2018, 206, 16-24. [CrossRef]

66. Lu, F.; Rodriguez-Garcia, J.; Van Damme, I.; Westwood, N.J.; Shaw, L.; Robinson, J.S.; Warren, G.; Chatzifragkou, A.; McQueen Mason, S.; Gomez, L.; et al. Valorisation strategies for cacao pod husk and its fractions. Curr. Opin. Green Sustain. Chem. 2018, 14, 80-88. [CrossRef]

67. Valero-Valdivieso, M.F.; Ortegón, Y.; Uscategui, Y. Biopolímeros: Avances y perspectivas. DYNA 2013, 80, 171-180.

68. Anyaoha, K.E.; Sakrabani, R.; Patchigolla, K.; Mouazen, A.M. Critical evaluation of oil palm fresh fruit bunch solid wastes as soil amendments: Prospects and challenges. Resour. Conserv. Recycl. 2018, 136, 399-409. [CrossRef]

69. Praveena, C.; Suresh, J.; Jegadeeswari, V.; Kannan, J.; Karthikeyan, S. Studies on composting of cacoa (Theobroma cacao L.) Pod husk. Int. J. Adv. Res. 2018, 6, 1081-1085. [CrossRef]

70. Kone, K.; Akueson, K.; Norval, G. On the Production of Potassium Carbonate from Cacao Pod Husks. Recycling 2020, 5, 23. [CrossRef]

71. SoDRé, G.A.; Venturini, M.T.; Ribeiro, D.O.; Marrocos, P.C.L. Extract from the bark of cacao fruit as potassium fertilizer on growth of cacao seedlings. Rev. Bras. Frutic. 2012, 34, 881-887. [CrossRef]

72. Aggrey, W.N.; Asiedu, N.Y.; Tackie-Otoo, B.N.; Stephen Adjei, E.M.-B. Performance of Carboxymethyl Cellulose Produced from Cacao Pod Husk as Fluid Loss Control Agent at High Temperatures and Variable (Low and High) Differential Pressure Conditions-Part 1. J. Pet. Sci. Technol. 2019, 9, 22-38.

73. Sarmiento Hernandez, J. Evaluación del Uso de la Cáscara de Cacao Como Sustituto Parcial de la Matriz Polimérica en la Obtención de Espumas de Poliuretano; Universidad de América: Bogotá, Colombia, 2019; Volume 6, pp. 5-10.

74. González, L.M.R. Aprovechamiento de la Cáscara de Cacao Para la Elaboración de un Biocomposito con Aplicación en la Construcción Sostenible; Universidad Del Bosque: Bogotá, Colombia, 2019; Volume 53.

75. Campos-Vega, R.; Nieto-Figueroa, K.H.; Oomah, B.D. Cacao (Theobroma cacao L.) pod husk: Renewable source of bioactive compounds. Trends Food Sci. Technol. 2018, 81, 172-184. [CrossRef]

76. Muñoz-Almagro, N.; Valadez-Carmona, L.; Mendiola, J.A.; Ibáñez, E.; Villamiel, M. Structural characterisation of pectin obtained from cacao pod husk. Comparison of conventional and subcritical water extraction. Carbohydr. Polym. 2019, 217, 69-78. [CrossRef]

77. Valadez-Carmona, L.; Plazola-Jacinto, C.P.; Hernández-Ortega, M.; Hernández-Navarro, M.D.; Villarreal, F.; NecoecheaMondragón, H.; Ortiz-Moreno, A.; Ceballos-Reyes, G. Effects of microwaves, hot air and freeze-drying on the phenolic compounds, antioxidant capacity, enzyme activity and microstructure of cacao pod husks (Theobroma cacao L.). Innov. Food Sci. Emerg. Technol. 2017, 41, 378-386. [CrossRef]

78. Vriesmann, L.C.; de Mello Castanho Amboni, R.D.; De Oliveira Petkowicz, C.L. Cacao pod husks (Theobroma cacao L.): Composition and hot-water-soluble pectins. Ind. Crops Prod. 2011, 34, 1173-1181. [CrossRef]

79. Vriesmann, L.C.; Teófilo, R.F.; Lúcia de Oliveira Petkowicz, C. Extraction and characterization of pectin from cacao pod husks (Theobroma cacao L.) with citric acid. LWT Food Sci. Technol. 2012, 49, 108-116. [CrossRef]

80. Vriesmann, L.C.; de Oliveira Petkowicz, C.L. Cacao pod husks as a source of low-methoxyl, highly acetylated pectins able to gel in acidic media. Int. J. Biol. Macromol. 2017, 101, 146-152. [CrossRef] [PubMed]

81. Diniz, D.M.; Druzian, J.I.; Audibert, S. Produção de goma xantana por cepas nativas de Xanthomonas campestris a partir de casca de cacau ou soro de leite. Polimeros 2012, 22, 278-281. [CrossRef] 
82. Lateef, A.; Oloke, J.K.; Gueguim Kana, E.B.; Oyeniyi, S.O.; Onifade, O.R.; Oyeleye, A.O.; Oladosu, O.C.; Oyelami, A.O. Improving the quality of agro-wastes by solid-state fermentation: Enhanced antioxidant activities and nutritional qualities. World J. Microbiol. Biotechnol. 2008, 24, 2369-2374. [CrossRef]

83. Abdul Karim, A.; Azlan, A.; Ismail, A.; Hashim, P.; Abd Gani, S.S.; Zainudin, B.H.; Abdullah, N.A. Efficacy of cacao pod extract as anti-wrinkle gel on human skin surface. J. Cosmet. Dermatol. 2016, 15, 283-295. [CrossRef]

84. Bean, C.; Chain, V. Customize the Report. Available online: https://www.mordorintelligence.com/industry-reports/cacaobeans-value-chain-analysis (accessed on 17 September 2020).

85. Porrini, G. Creative Cacao. Available online: https:/ / www.creativecacao.com/the-cacao-international-value-chain-how-manyactors-are-involved-between-the-cacao-plantation-to-chocolate-shop (accessed on 10 December 2020).

86. Biopro Bw BIOPRO Baden-Württemberg. Available online: https:/ / www.biooekonomie-bw.de/en/bw/location\# (accessed on 9 October 2020). 